Loyalitas Kreativitas

Aldi Masyarakat Kreatif
P-ISSN 2722-2101, E-ISSN 2722-4201

Program Studi Ekonomi Manajemen Universitas Pamulang

Jurnal LOKABMAS Kreatif Vol.02,No.02,Juli 2021 Hal. 1-9

Email:jurnalkreatif.manajemen@gmail.com

\title{
DARING ATAU KEGIATAN TATAP MUKA EFESIENSI MANA
}

\section{Veta Delimah Pasaribu ${ }^{1}$, Fajar Isti Qomah ${ }^{2}$, Sinta Rahmi Sajida ${ }^{3}$, Defira Oktaviani Putri ${ }^{4}$, Mulki Kemal Hidayat ${ }^{5}$, Ridho Senoaji $^{6}$}

\author{
${ }^{1}$ Dosen Prodi Manajemen Fakultas Ekonomi Universitas Pamulang \\ 2,3,4,5,6 Mahasiswa Manajemen Universitas Pamulang \\ Email : veta01889@unpam.ac.id , Fajaristiqomah981@gmail.com, \\ rahmisinta1@gmail.com, defira25@gmail.com, mulkik64@gmail.com, \\ Ridhosenoaji13@gmail.com
}

\begin{abstract}
ABSTRAK
Abstrak: Tujuan dari kegiatan Pengabdian Kepada Masyarakat ini adalah untuk melaksanakan salah satu Tugas PKM di Perguruan Tinggi. Selain itu, melalui kegiatan Pengabdian Kepada Masyarakat ini mahasiswa diharapkan dapat memberikan kontribusi besar kepada pengembangan dan penerapan keilmuan dalam masyarakat.

Metode kegiatan yang digunakan adalah tim pelaksana mengunjungi Karang Taruna Kelurahan Pamulang barat Kota Tangerang Selatan dan memberikan penyuluhan tanggal 21 Maret 2021. Kegiatan pengabdian dilakukan dengan cara memberikan penyuluhan mengenai apa yang perlu diperhatikan dalam menghadapi wabah covid 19 diantaranya mensurvei kegiatan Daring atau kegiatan Tatap Muka yang lebih diminati dan efisien dalam era pandemik saat ini.

Masa pandemi covid-19 seperti ini, pilihan Kegiatan Daring lebih banyak direkomendasi untuk mengurangi pertemuan dari keramaian. Di tengah situasi yang serba tidak pasti seperti sekarang ini orang-orang bisa dengan mudah mengalami putus asa yang tentunya hal ini juga bisa menyebabkan stres yang meningkat. Dengan memberikan penyuluhan, maka Karang Taruna memperoleh berbagai macam informasi dan strategi-strategi mengenai bagaimana untuk tetap produktif selama menghadapi wabah covid 19 .
\end{abstract}

\section{Kata Kunci: Efektifitas, kegiatan Daring, Covid-19}

Abstract : The purpose of this Community Service activity is to carry out one of the PKM Duties in Higher Education. In addition, through this Community Service activity, students are expected to make a major contribution to the development and application of science in society.

The activity method used was the implementing team visiting the Karang Taruna, Pamulang barat Village, South Tangerang City and providing counseling on March 21, 2021. Community service activities are carried out by providing counseling about what needs to be considered in dealing with the Covid 19 outbreak, including surveying online activities or face-to-face activities that more desirable and efficient in the current pandemic era.

During the Covid-19 pandemic like this, the choice of Online Activities is recommended more to reduce gatherings from crowds. In the midst of a situation that is completely uncertain like now, people can easily experience despair, which of course can also cause increased stress. By providing counseling, Karang Taruna obtained various kinds of information and strategies on how to stay productive during the Covid 19 outbreak.

Keywords: Effectiveness, activity Online Learning, Covid-19 


\section{PENDAHULUAN}

Saat ini berbagai negara di belahan dunia, tengahdilanda dengan wabah suatu penyakit yang disebabkan oleh virus bernama corona atau lebih dikenal dengan istilah covid-19 (Corona Virus Diseases19). Virus ini awalnya mulai berkembang di Wuhan, China. Wabah virus ini memang penularannya sangat cepat menyebar ke berbagai negara di dunia. Sehingga oleh World Health Organization (WHO), menyatakan wabahpenyebaran virus covid19 sebagai pandemi dunia saat ini.

Sudah banyak orang di seluruh dunia yang terpapar dengan virus ini, bahkan menjadi korban kemudian meninggal dunia. Wabah virus ini telah memakan banyak korban seperti tercatat di negara Tiongkok, Italia, Spanyol dan negara besar lain didunia. Penyebaran virus ini baru dapat dikenali sekitar 14 hari. Namun, orang yang telah terpapar dengan virus ini memilikigejala seperti demam di atas suhu normal manusia atau diatas suhu $38 \mathrm{C}$, gangguan pernafasan seperti batuk, sesak nafas serta dengan gejala lainnya seperti gangguan tenggorokan, mual, dan pilek. Apabila gejala tersebut sudah dirasakan, maka perlu adanya karantina mandiri (self quarantine).

Penyebaran virus covid-19 menjadi penyebab angka kematian yang paling tinggi di berbagai negara dunia saat ini. Sudah banyak korban yang meninggal dunia. Bahkan banyak juga tenaga medis yang menjadi korban lalu meninggal. Hal ini menjadi permasalahan yang harus dihadapi oleh dunia saat ini, untuk melakukan berbagai kebijakan termasuk di negara Indonesia sendiri. Indonesia pun juga merasakan akan dampak penyebaran virus ini. Semakin hari semakin cepat menyebar ke sejumlah wilayah di Indonesia.

Akibat dari pandemi covid-19 ini, menyebabkan diterapkanna berbagai kebijakan untuk memutus mata rantai penyebaran virus covid-19 di Indonesia. Upaya yang dilakukan oleh pemerintah di Indonesia salah satunya dengan menerapkan himbauan kepadamasyarakat agar melakukan physical distancing yaitu himbauan untuk menjaga jarak diantara masyarakat, menjauhi aktivitas dalam segala bentuk kerumunan, perkumpulan, dan menghindari adanya pertemuan yang melibatkan banyak orang.

Upaya tersebut ditujukan kepada masyarakat agar dapat dilakukan untuk memutusrantai penyebaran pandemi covid19 yang terjadisaat ini.

Pemerintah menerapkan kebijakan yaitu Work From Home (WFH). Kebijakan ini merupakan upaya yang diterapkan kepada masyarakat agar dapat menyelesaikan segala pekerjaan di rumah. Dengan adanya pembatasan interaksi, Peraturan Daerah di Indonesia juga mengeluarkan kebijakan yaitu dengan meliburkan para pekerja dan mengganti proses Kegiatan Di Kelurahan dengan menggunakan sistem dalam jaringan (daring) berdasarkan " Perwal Nomor 2 Tahun 2021 dan Surat Edaran No. 443.1/27Bag.Hukum/2021 tersebut, membahas tentang sejumlah ketentuan pada pelaksanaan PPKM di wilayah Kota Tangerang.

Dengan menggunakan kegiatan secara daring ini,terkadang muncul berbagai masalah yang dihadapi oleh anggota karang taruna, seperti penugasan yang belum selesai disampaikan secara online dan dikirimkan secara online.

Berbagai media komunikasi jarak jauh pun dicoba dan digunakan. Sarana yang dapat digunakansebagai media pembelajaran online antaralain, Schoology, google classroom, Google Form, whatsapp grup dan media lainnya. Sarana-sarana tersebut merupakan sarana yang dipilih untuk pembelajaran daring dilakukan di karang taruna pamulang barat. Sarana sarana tersebut digunakan secara maksimal,sebagai media dalam melangsungkan komunikasi seperti di rapat. Dengan menggunakan media online tersebut, maka secara tidak langsung kemampuan menggunakan serta mengakses teknologi semakin dikuasai oleh antar anggota. 
Loyalitas Kreativitas

Aldi Masyarakat Kreatif
P-ISSN 2722-2101, E-ISSN 2722-4201

Program Studi Ekonomi Manajemen Universitas Pamulang

Jurnal LOKABMAS Kreatif Vol.02,No.02,Juli 2021 Hal. 1-9

Email:jurnalkreatif.manajemen@gmail.com
Setelah anggota mampu menguasai berbagai sarana penugasan kerja daring (online), maka akan tercipta pemikiran mengenai metode dan model pembelajaran lebih bervariasi yang belum pernah dilakukan oleh pendidik. Misalnya, guru membuat konten video kreatif sebagai bahan pengajaran. Dalam hal ini, anggota karang taruna lebih persuasif karena membuat semakin tertarik dengan materi yang diberikan oleh pemateri/ atasan melalui video kreatif tersebut. Anggota karang taruna tentu akan dapat memahami apa yang dijelaskan oleh pemateri melalui video kreatif yang dibuat oleh pemateri tersebut. Sehingga dengan adanya penerapan model penugasan kerja di rumah ini, membuat anggota karang taruna tidak merasa bosan dalam mengikuti pekerjaannya secara daring (online).

Penggunaan teknologi dalam menyelesaikan tugas pada anggota, juga dapat menimbulkan kreativitas dikalangan anggota dalam mengembangkan pengetahuan yang telah mereka miliki. Dengan metode pembelajaran yang bervariasi dari anggota, mereka dapat menciptakan suatu produk pembelajaran kreatif yang dapat mengembangkan pemikiran melalui analisis mereka sendiri, tanpa keluar dari pokok bahasan materi yang telahdisampaikan oleh pemateri..

\section{PENELITIAN YANG TERKAIT}

Kegiatan daring merupakan solusi untuk tetap melaksanakan kegiatan kerja di rumah antar anggota karang taruna. Ada beberapa penelitian lain terkait penelitian ini.

Roida Pkpahan, Yuni Fitriani (2020) melakukan

penelitian yang berjudul "Analisa Pemanfaatan Teknologi Informasi Dalam Pembelajaran Jarak Jauh di Tengah Pandemi Virus Corona Covid-19" pemanfaatan teknologi informasi memiliki peranan yang sangat penting dalam pelaksanaan kegiatan jarak jauh ditengah pandemi virus corona covid19, proses kegiatan daring bisa berjalan dengan baik dengan adanya teknologi informasi yang sudah berkembang pesat saat ini diantaranya elearning, google class, whatsapp, zoom serta media infromasi lainnya serta jaringan internet yang dapat menghubungkan antar pekerja sehingga proses kegiatan online dapat berjalan dengan baik sebagai mana mestinya meskipun ditengah pandemi virus corona covid-19.[1]

Albitar Septian Syarifudin (2020) melakukan penelitan yang berjudul “ Implementasi kegiatan Daring Untuk Meningkatkan Mutu Anggota Karang Taruna sebagai Dampak diterapkannya Social Distancing" kegiatan daring merupakan kegiatan yang dilakukan menggunakan internet sebagai tempat menyalurkan informasi yang harus diiinformasikan secara tepat. Bentuk kegiatan seperti ini dapat dilakukan kapanpun dan dimanapun tanpa terikat waktu dan tanpa harus bertatap muka. Di era perkembangan teknologi pembelajaran daring semakin canggih dengan berbagai aplikasi dan fitur yang semakin memudahkan pengguna. Tidak terikatnya waktu dan dialkukan tanpa bertatap muka menjadi keunggulan kegiatan daring yang bias dimanfaatkan anggota. Seperti yang terjadi pada saat ini, pembelajaran daring menjadi satu-satunya pilihan bentuk penyelesaian komunikasi yang dapat dilakukan oleh anggota. ketika terjadi bencana alam atau pandemi global. Indonesia menerapkan social distance di segala aspek kehidupan termasuk dunia pendidikan. Oleh karena itu, pembelajaran daring dapat dikatakan menjadi satusatunya pilihan pembelajaran yang dapat dilakukan oleh pendidik untuk menigkatkan mutu pembelajaran di Indonesia.[2]

Hikmat, Endang Hermawan, Aldim, Irwandi (2020) melakukan penelitian dengan judul "Efektivitas kegiatan Daring Selama Masa Pandemi Covid-19: Sebuah Survey Online" kebijakan kegiatan dari rumah dengan memberlakukan pembelajaran daring menggunakan aplikasi Zoom untuk tatap muka dan WhatsApp untuk memberikan informasi serta penugasan untuk media belajar daring. 
Hasil pengujiannya didapatkan bahwa belajar secara daring dengan Zoom dan WhatsApp hanya efektif bagi komunikasi antar anggota, sedangkan pada menyelesaikan pekerjaan secara online kurang efektif. [3]

\section{TELAAH PUSTAKA}

\section{a. Virus Corona Covid-19}

Corona virus merupakan keluarga besar virus yang menyebabkan penyakit pada manusia dan hewan. Pada manusia biasanya menyebabkan

penyakit infeksi saluran pernapasan, mulai flu biasa hingga penyakit yang serius seperti Middle EastRespiratory Syndrome (MERS) dan Sindrom Pernafasan Akut Berat/ Severe Acute Respiratory Syndrome (SARS). Coronavirus jenis baru yang ditemukan pada manusia sejak kejadian luar biasa muncul di Wuhan Cina, pada Desember 2019, kemudian diberi nama Severe Acute Respiratory Syndrome Coronavirus 2 (SARS-COV2), dan menyebabkan penyakit Coronavirus Disease-2019(COVID-19). [4]

Gejala awal infeksi virus Corona atau COVID- 19 bisa menyerupai gejala flu, yaitu demam, pilek, batuk kering, sakit tenggorokan, dan sakit kepala. Setelah itu, gejala dapat hilang dan sembuh atau malah memberat. Penderita dengan gejala yang berat bisa mengalami demam tinggi, batuk berdahak bahkan berdarah, sesak napas, dan nyeri dada. Gejala-gejala tersebut muncul ketika tubuh bereaksi melawan virus Corona.[5]

Secara umum, ada 3 gejala umum yang bisamenandakan seseorang terinfeksi virus Corona, yaitu:

- Demam (suhu tubuh di atas 38 derajatCelsius)

- Batuk kering

- Sesak napas

Ada beberapa gelajala lain yang juga bisa muncul pada infeksi virus Corona meskipun lebih jarang, yaitu:

- Diare

- Sakit kepala

- Konjungtivitis
- Hilangnya kemampuan mengecap rasa ataumencium bau

- Ruam di kulit

Gejala-gejala COVID-19 ini umumnya munculdalam waktu 2 hari sampai 2 minggu setelah penderita terpapar virus Corona.

\section{b. Kegiatan Daring (online)}

Kegiatan Daring merupakan kepanjangan dari Kegiatan dalan jaringan (online) dengan pola pembelajarannya melalui bantuan jaringan internet sehingga akan terjadi interaksi kegiatan jarak jauh antar anggota karang taruna. Kegiatan daring ini juga dilakukan memanfaatkan teknologi informasi.

Menurut Dabbagh dan Ritland (dalam Arnesi dan Hamid, 2015) kegiatan daring (online) adalah sistem belajar yang terbuka dan tersebar dengan menggunakan perangkat pedagogi (alat bantu kegiatan), yang dimungkinkan melalui internet dan teknologi berbasis jaringan untuk memfasilitasi pembentukan proses belajar dan pengetahuan melalui aksi dan interaksi yang berarti.[6]

Media kegiatan online dapat diartikan sebagai media yang dilengkapi dengan alat pengontrol yang dapat dioperasikan oleh pengguna (user), sehingga pengguna (user) dapat mengendalikan dan mengakses apa yang menjadi kebutuhan pengguna, misalnya mengunduh sumber-sumber.

Keuntungan penggunaan media kegiatan online adalah kegiatan bersifat mandiri dan interaktivitas yang tinggi, mampu meningkatkan tingkat ingatan, memberikan lebih banyak pengalaman belajar, dengan teks, audio, video dan animasi yang semuanya digunakan untuk menyampaikan informasi, dan juga memberikan kemudahan menyampaikan, meng-update isi, mengunduh, para anggota juga bisa mengirim email kepada anggota lain, mengirim komentar pada forum diskusi, memakai ruang chat, hingga link video conference untuk berkomunikasi langsung.

Selanjutnya Dabbagh dan Ritland mengatakan ada tiga komponen pada kegiatan online yaitu : (a) model kegiatan, (b) strategi instruksional dan kegiatan, (c) media kegiatan online. Ketiga komponen ini 
Loyalitas Kreativitas

Aldi Masyarakat Kreatif
P-ISSN 2722-2101, E-ISSN 2722-4201

Program Studi Ekonomi Manajemen Universitas Pamulang

Jurnal LOKABMAS Kreatif Vol.02,No.02,Juli 2021 Hal. 1-9

Email:jurnalkreatif.manajemen@gmail.com membentuk suatu keterkaitan interaktif, yang didalamya terdapat model pembelajaran yang tersusun sebagai suatu proses sosial yang menginformasikan desain dari lingkungan kegiatan online, yang mengarah ke spesifikasi strategi instruksional dan kegiatan yang secara khusus memungkinkan untukmemudahkan belajar melalui penggunaan teknologi.

\section{c. Schoology}

Schoology merupakan salah satu platform inovatif yang dibangun berdasarkan inspirasi dari media sosial facebook dengan tujuan untuk kepentingan kegiatan online. Platform ini dikembangkan pada tahun 2009 di New York (Besana S.: 2012). Schoology membantu guru dalam membuka kesempatan komunikasi yang luas kepada anggota karang taruna dapat lebih mudah untuk mengambil peran/bagian dalam diskusi dan kerja sama dalam tim. Selain itu, Schoology juga didukung oleh berbagai bentuk media seperti video, audio dan gambar yang dapat menarik minat anggota. Schoology mengarahkan anggota mengaplikasikan penggunaan tekonologi dalam kgiatan. Dengan demikian Schoology adalah sebuah layanan gratis. yang menggunakan konsep pengelolaan kegiatan sosial yang dikhususkan untuk membangun kegiatan online yang aman untuk berbagi informasi serta fitur-fitur atau konten pemateri baik berbentuk tulisan, file dan link yang dapat 27 dibagikan baik bagi antar anggota. Dan juga fitur khusus berupa courses, groups dan resources. Schoology memiliki fitur yang sangat mendukung aktifitas kegiatan. [7]

Adapun fitur-fitur yang dimiliki oleh Schoology

adalah sebagai berikut:

1. Courses (Kursus), yaitu fasilitas untuk membuat kursus. Fasilitas Courses ini juga ada di Moodle.

2. Groups (Kelompok), yaitu fasilitas untuk membuat kelompok dalam pengelompokkan suatu tugas yang dikerjakan berdasarkan kelompokkelompok dalam tema yang berbeda atau pengelompokan. Fasilitas ini juga ada di Moodle maupun di Facebook.

3. Resources (Sumber Belajar), yaitu fasilitas yangberfungsi untuk menyajikan sumber belajar ke pribadi maupun kelompok Google Classroom

\section{d. Google classroom}

memiliki beberapa fitur yang dapat digunakan dalam proses kegiatan antara lain halaman utama yang dapat menampilkan tugas kerja, penyusunan kerja, penyimpanan data di google drive, dan dapat diakses melalui smartphone, selain itu juga dapat menampung semua jenis file, serta dapat menambahkan gambar profil. Selain itu terdapat pula fitur lain yang dapat digunakan oleh pemateri dalam mengembangkan materi pemateri karang taruna yaitu reuse post, create question, create assignment, dan create topic. Google classroom bisa dikatakan salah satu media kegiatan online yang berbasis metode pembelajaran inkuiri karena google classroom dapat melibatkan kemampuan anggota secara maksimal dalam mencari, memahami, menyelidiki, menganalisis dan merumuskan hasil belajar (Gofur, 2018). Salah satu fitur yang akan sering digunakan oleh para pemateri dalam menggunakan google classroom adalah create assignment yang berfungsi untuk memberikan tugas kepada anggota. selain itu terdapat fitur create topic yang tidak kalah menarik dari fitur lainnya yaitu bisa digunakan untuk membuat topik penugasan kerja yang akan dibahas di kelas virtual google classroom sehingga anggota karang taruna bisa berpartisipasi aktif dalam penyelesaian tugas kerja baik yang dilakukan secara tatap muka langsung maupun di google classroom (Hapsari dan Pamungkas, 2019). [8] [9]

Google classroom bertujuan untuk memberikan kemudahan dalam membuat dan memberikan tugas kepada annggota karang taruna yang bersifat paperless. Penguasaan dalam google classroom berupa dokumen video dan diskusi.

Selain itu juga bisa melakukan tes online menggunakan format Google Form dengan berbagai tipe soal. Untuk login ke google 
Loyalitas Kreativitas

Aldi Masyarakat Kreatif
P-ISSN 2722-2101, E-ISSN 2722-4201

Program Studi Ekonomi Manajemen Universitas Pamulang

Jurnal LOKABMAS Kreatif Vol.02,No.02,Juli 2021 Hal. 1-9

Email:jurnalkreatif.manajemen@gmail.com classroom, pengguna akun gmail hanya mencari dan klik menu google classroom yang sudah tersedia di akun gmail yang bersangkutan (Muslik, 2019). [10]

\section{e. Google Form}

Google Form adalah aplikasi administrasi survei yang termasuk dalam suite kantor Google Drivebersama dengan Google Documents, Google Sheets, dan Google Slides. Formulir menampilkan semua fitur kolaborasi dan berbagi yang ditemukan di Documents, Spreadsheet, dan Slide. [11] Google Form adalah alat yang memungkinkan pengumpulan informasi dari pengguna melalui survei atau kuis yang dipersonalisasi. Informasi tersebut kemudian dikumpulkan dan secara otomatis terhubung ke spreadsheet. Spreadsheet diisi dengan survei dan respons kuis. Layanan Formulir telah mengalami beberapa pembaruan selama bertahun- tahun. Fitur-fitur baru termasuk, tetapi tidak terbataspada, pencarian menu, shuffle pertanyaan untuk pesanan acak, membatasi tanggapan untuk sekali per orang, URL yang lebih pendek, tema khusus, secaraotomatis menghasilkan saran jawaban saat membuatformulir, dan " Opsi unggah file "untuk pengguna menjawab pertanyaan yang mengharuskan mereka untuk berbagi konten atau file dari komputer merekaatau Google Drive. Fitur unggahan hanya tersedia melalui G Suite. Pada Oktober 2014, Google memperkenalkan add-on untuk google form, yang memungkinkan pengembang pihak ketiga untuk membuat alat baru untuk lebih banyak fitur dalam survei.

Pada bulan Juli 2017, Google memperbarui Formulir untuk menambahkan beberapa fitur baru. "Validasi respons cerdas" mampu mendeteksi input teks dalam bidang formulir untuk mengidentifikasi apa yang tertulis dan meminta pengguna untuk mengoreksi informasi jika salah memasukkan. Bergantung pada pengaturan berbagi file di Google Drive, pengguna dapat meminta unggahan file dari individu di luar perusahaan masing-masing, dengan batas penyimpanan awalnya sebesar $1 \mathrm{~GB}$, yang dapat diubah menjadi 1 TB. Kotak centang baru memungkinkan jawaban multi-opsi dalam tabel. Di Pengaturan, pengguna dapat membuat perubahan yang memengaruhi semua formulir baru, seperti selalu mengumpulkan alamat email.

\section{f. Whatsapp}

WhatsApp merupakan salah media komunikasi yang sangat popular yang digunakan saat ini, whats up merupakan salah satu aplikasi yang digunakan untuk melakukan percapkan baik menggunakan teks, suara, maupun video. WhatsApp1 untuk tetap terhubung dengan teman dan keluarga, kapan pun, di mana pun. WhatsApp gratis2 dan menawarkan pengalaman bertukar pesan dan panggilan yang sederhana, aman, reliabel, tersedia pada telepon di seluruh dunia.

(https://www.whatsapp.com/about/?lang=id ).

Selanjutnya menurut Niken, Sekretaris Jenderal Kementerian Komunikasi dan Informatika, WhatsApp adalah aplikasi yang paling diminati masyarakat dalam berkomunikasi lewat internet. " $83 \%$ dari 171 juta pengguna internet kita adalah pengguna WhatsApp yang menghubungkan antara masyrakat" hal tersebut diungkapkan Niken dalam peluncurn program edukasi "Literasi Privasi dan Keamanan Digital" di Kementrian Komunikasi dan Informatika (Kominfo), Jakarta, Senin 18/11/2020.

\section{g. Kegiatan Daring (offline)}

Dalam kontek Kegiatan Online,

khususnya pada masa pandemic sekarang ini perlu adanya keputusan demoratis dalam melaksanakan pembelajaran, salah satunya yaitu memadukan penggunaan sumber komunikasi tradisional (offline) dan online; pemaduan ini berfungsi untuk menjembatani derasnya arus penyebaan sumber penugasan kerja daring dan kesulitan melepaskan diri dari pemanfaatan sumber- sumber penyelesaian tugas kerja yang digunakan 
dalam ruang online. Artinya, bagaimanapun canggihnya teknologi yang digunakan belum mampu menggantikan pelaksanaan

kegiatan offline karena metode interaksi tatap muka konvensional masih jauh lebih efektif dibandingkan pembelajaran online. Selain itu, keterbatasan dalam aksesibilitas Internet, perangkat keras (hardware) dan perangkat lunak (software), serta pembiayaan sering menjadi hambatan dalam memaksimalkan sumber-sumber kegiatan online. Menurut survei kegiatan offline lebih efektif guna memberikan materi dengan mudah dan cepat tanngap tidak terfokus dengan alat komunikasi (Yaumi, 2018).

$$
\text { Seiring kebijakan yang }
$$

dikeluarkan tentunya tidak dapat memastikan semuanya akan berjalan sebagaimana mestinya disemua kalangan, khusus nya bagi kelurahan yang berada di daerah pedesaan yang kekurangan fasilitas berupa teknologi terpadu guna menunjang proses kegiatan online. Kurangnya biaya dan fasilitas yang memadai antara perda dan selaku anggota karang taruna membuat proses kegiatan online tidaklah seefektif yang diharapkan.

\section{Realisasi Pemecahan Masalah}

Berdasarkan solusi yang diusulkan maka target yang diharapkan sebagai berikut:

1. Anggota di karang taruna kelurahan pamulang barat memahami tentang kefektifan pembelajaran daring maupun offline, tujuan dan manfaat dari pembelajaran daring dan offline dalam upaya meningkatkan kegiatan online.

2. Anggota Karang Taruna di Kelurahan Pamulang Barat memahami tentang Kegiatan baik sisi pemateri maupun antar anggota dalam mengembangkan potensi minat kegiatan untuk meningkatkan penguasaan materi.

3. Perangkat pemateri membantu untuk terus menerus memberikan materi kegiatan secara kreatif dan inovatif agar materi bisa dipahami dengan baik.

\author{
Khalayak Sasaran \\ Peserta kegiatan : Anggota Karang \\ Taruna
}

Tempat dan Waktu

Tempat Kegiatan di Karang Taruna

Kelurahan Pamulang Barat

Waktu Pelaksanaan : Minggu, 21 Maret 2021, Jam $12.30 \mathrm{~s} / \mathrm{d} 17.00$.

\section{Metode Kegiatan}

Metode yang digunakan dalam kegiatan Pengabdian Kepada Masyarakat (PKM) ini adalah melalui kegiatan penyuluhan kepada Anggota Karang taruna, tentang :

a. Pemahaman pengefektivan kegiatan online maupun offline dalam mengembangkan potensi minat kegiatan.

Adapun metode sebelum dan sesudah pelaksanaan PKM, adalah sebagai berikut : 1). Metode Pengumpulan Data Untuk memperoleh data yang akurat yang dapat dipercaya kebenarannya dan relevan, maka pengumpulan data dilakukan dengan beberapa metode yaitu :

a. Wawancara

Merupakan proses untuk memperoleh data dengan cara melakukan pertanyaan, dalam hal ini dilakukan dengan

b. Observasi

Merupakan proses pengumpulan data dengan mengadakan pengamatan langsung pada objek Pengabdian Kepada Masyarakat (PKM) untuk memperoleh data yang diperlukan, dengan melakukan survey langsung ke tempat PKM.

c. Fokus Grup Diskusi (FGD)

Merupakan proses pengumpulan data dengan cara diskusi kelompok secara sistematis dan terarah mengenai pokok permasalahn Pengabdian Kepada Masyarakat (PKM). Dalam hal ini FGD dilakukan dengan

d. Dokumen

Dokumen merupakan catatan peristiwa yang sudah berlalu, biasanya berbentuk tulisan, gambar, atau karya-karya monumental dari seseorang. Studi dokumen merupakan pelengkap dari 
penggunaan observasi dan wawancara. Dalam hal ini dilakukan dokumentasi berupa surat menyurat melakukan PKM

2) Metode Pelaksanaan

Metode pelaksanaan kegiatan ini berupa penyuluhan kepada anggota, Adapun tahapan yang dilakukan adalah sebagai berikut :

\section{Tahap Persiapan}

Tahap persiapan yang dilakukan meliputi

a. Informasi awal, pada tahap ini didapatkan infomasi awal dari salah satu anggota yang menginformasikan bahwa anggota belum memahami secara optimal peran kegiatan daring maupun offline dengan baik.

b. Pemantapan dan penentuan lokasi dan sasaran. Setelah informasi awal maka ditentukan lokasi pelaksanaan dan sasaran peserta kegiatan penyuluhan. Dengan melakukan proses perijinan secara lisan terlebih dahulu untuk diadakan PKM di lokasi tersebut kepada Bpk. Supriyadi SE,MSi dan setelah persetujuan ditentukan waktu pelaksanaan PKM yang akan diadakan pada tanggal 21 Maret 2021 dan bertempat di karang taruna kelurahan pamulang barat dengan jumlah peserta sebanyak 30 orang,

c. Penyusunan bahan/materi penyuluhan yang meliputi: slide presentasi (power point) dan makalah/materi untuk kegiatan penyuluhan berupa materi kegiatan online baik untuk anggota dengan sumber referensi dari bukubuku, jurnal maupun internet.

d. Persiapan perlengkapan penyuluhan, laptop dan LCD, spanduk kegiatan.

3) Tahap Pelaksanaan Penyuluhan

Tahap ini akan menjelasan tentang materi kegiatan online baik untuk antar anggota di mana sesi ini menitikberatkan pada pemaparan materi mengenai pengembangan potensi untuk mencapai keefisiensi dalam mengerjakan penyelesaian kerja antar anggota, selanjutnya dilakukan tahap diskusi dan tanya jawab.

4) Metode tanya jawab sangat penting bagi para peserta pelatihan. Metode ini memberi kesempatan kepada peserta untuk menanyakan hal-hal yang masih kurang atau belum jelas dalam penyuluhan yang sudah disampaikan.

\section{HASIL DAN PEMBAHASAN}

Anggota di dalam mengikuti penyuluhan sangat bersemangat dan antusias sehingga hasil kegiatan sangat memuaskan, disamping karena belum pernah mendapatkan informasi secara detail dan jelas dan kurangnya informasi yang akurat mengenai kegiatan daring maupun offline.

Dalam tanya jawab, juga peserta cukup banyak yang bertanya seputar kegiatan online dan fungsinya serta manfaat yang akan di dapat oleh anggota. Pada tahap akhir dilakukan pengisian angket/kuesioener mengenai pemahaman kegiatan online dalam mengembangkan minat anggota falam bekerja, sebagai tolak ukur hasil kegiatan PKM ini bisa bermanfaat untuk antar anggota.

\section{Pembahasan}

\section{Minggu, 21 Maret 2021}

Kegiatan intinya berupa penyuluhan dengan penyampaian materi tentang dasar-dasar pengefektivan kegiatan daring maupun offline dengan tujuan untuk mengetahui secara optimal bagaimana anggota memahami peran sebagai pekerja, selanjutnya dilakukan tahap diskusi dan tanya jawab. Penyampaian materi diberikan oleh tim PKM..

\section{KESIMPULAN DAN SARAN \\ Kesimpulan}

Berdasarkan hasil analisis, maka dapat ditarik kesimpulan bahwa, kegiatan daring untuk anggota karang taruna di kelurahan pamulang barat kurang efektif dan berbanding lurus dengan pemahanan anggota yaitu kurang paham dengan kegiatan online yang diberikan pemateri / atasan melalui kegiatan daring. Efektifitas kegiatan daring saat pandemi Covid-19 yaitu dengan menggunakan aplikasi google 
Loyalitas Kreativitas

Aldi Masyarakat Kreatif
P-ISSN 2722-2101, E-ISSN 2722-4201

Program Studi Ekonomi Manajemen Universitas Pamulang

Jurnal LOKABMAS Kreatif Vol.02,No.02,Juli 2021 Hal. 1-9

Email:jurnalkreatif.manajemen@gmail.com classroom dan model pembelajarannya menggunakan modul/buku yang dipegang oleh para anggota karang taruna serta jenis jenis tugas yang dapat dipahami oleh anggota karang taruna adalah tugas pekerjaan yang tidak dikomunikasikan dengan baik. Media yang digunakan siswa untuk kegiatan daring 97,7 \% menggunakan gadget (HP) dan kendala yang dihadapi anggota dalam kegiatan daring adalah kendala dari kuota data yang terbatas dan jaringan internet yang lambat.

Dengan diadakannya kegiatan PKM ini dapat diambil kesimpulan sebagai berikut :

1. Anggota Karang taruna belum semuanya memahami secara optimal metode kegiatan daring dikarenakan masih kurangnya ketidakpengetahuan teknologi secara online.

2. Anggota karang taruna belum semuanya memanfaatkan secara optimal dalam mengembangkan potensi pembelajaran daring yang ada di wilayahnya dikarenakan kurangnya alat teknologi seperti alat komunikasi digital.

\section{Saran}

1. Perlu adanya komunikasi yang baik antar anggota karang taruna supaya tidak merasa ada yang dirugikan dari kegiatan daring dan informasi bisa diserap dengan baik oleh anggota.

2. Perlu dukungan baik dari atasan untuk lebih fokus pada kegiatan untuk penilaian prestasi anggota karang taruna secara obyektif.

\section{DAFTAR PUSTAKA}

[1] Syarifudin, Albitar Septian. (2020). Implementasi kegiatan Daring Untuk Meningkatkan Mutu Pendidikan sebagai Dampak diterapkannya Social Distancing. Universitas Trunojoyo Madura.

[2] Hikmat., Hermawan, Endang., Aldim., Irwandi. (2020). Efektivitas kegiatan Daring Selama Masa Pandemi Covid19: Sebuah Survey Online. UIN Sunan Gunung Djati Bandung.

[3] Hui, D. S., E., I. A., Madani, T. A.,
Ntoumi, F., Kock, R., Dar, O., et al. (2020, Februari). The continuing 2019$\mathrm{nCoV}$ epidemic threat of novel coronaviruses to global health - The latest 2019novel coronavirus outbreak in Wuhan, China. International Journal of Infectious Diseases, 91, 264-66.

[4] Dr. Merry Dame Cristy Pane. (2020, Mei).VirusCorona (COVID-19). Online di https://www.alodokter.com/viruscorona Di Unduh pada tanggal $30 \mathrm{Mei}$ 2020

[5] Stefano, Besana. 2012. Schoology: Il Learning Management System Diventa Social. Online di https://en.wikipedia.org/wiki/Schoology Diunduh tanggal 30 Mei 2020

[6] Hapsari, S., dan Pamungkas, H. 2019. Pemanfaatan Google Classroom sebagai Media kegiatan Online di Universitas Dian Nuswantoro. Wacana, 18(2), 225233.

[7] Dr. Merry Dame Cristy Pane. (2020, Mei).VirusCorona (COVID-19). Online di https://www.alodokter.com/viruscorona Di Unduh pada tanggal $30 \mathrm{Mei}$ 2020

[8] Stefano, Besana. 2012. Schoology: Il Learning Management System Diventa Social. Online di https://en.wikipedia.org/wiki/Schoology Diunduh tanggal 30 Mei 2020

[9] Gofur, A. 2018. Using Google Classroom on Inquiry Based Learning to Improve Student's

[10] Elburdah, R. P., Pasaribu, V. L. D., Rahayu, S., Septiani, F., \& Metarini, R. R. A. (2021). Mompreneur Penopang Perekonomian Keluarga Di Masa Pandemi Covid-19 Dengan Bisnis Online Pada Kelurahan Pondok Benda. Abdi Laksana: Jurnal Pengabdian Kepada Masyarakat, 2(1), 75-82.

[11] Pasaribu, V. L. D., Agrasadya, A., Shabrina, N., \& Krisnaldy, K. (2020). Menjadi Enterpreneur Muda Yang Memiliki Jiwa Leadership Untuk Menghadapi Masa Depan. Abdi Laksana: Jurnal Pengabdian Kepada Masyarakat, 1(1). 
Loyalitas Kreativitas

Aldi Masyarakat Kreatif
P-ISSN 2722-2101, E-ISSN 2722-4201

Program Studi Ekonomi Manajemen Universitas Pamulang Jurnal LOKABMAS Kreatif Vol.02,No.02,Juli 2021 Hal. 1-9 Email:jurnalkreatif.manajemen@gmail.com
[12] Pasaribu, V. L. D., Susanti, F., \& Hartuti, E. T. K. (2019). Memotivasi Siswa dan Siswi SMK Letris Indonesia di Dalam Menentukan Pilihan Untuk Melanjutkan Pendidikan Atau Bekerja Setelah Lulus Sekolah. Jurnal Pengabdian Dharma Laksana, 1(2), 161-172.

[13] Pasaribu, V. L. D., Sulaiman, S., Sutiman, S., Thaharudin, T., \& Purnomo, B. Y. (2020). Pengenalan Letak Posyandu Terdekat Dikelurahan Pisangan Dengan Manajemen Pemasaran Revolusi 4.0 Untuk Meningkatkan Pengetahuan Masyarakat Letak Dan Fungsi Posyandu Terdekat Pada Kelurahan Pisangan. Dedikasi Pkm, l(1), 105-110.

[14] Pasaribu, V. L. D., Oktrima, B., Prabowo, B., Arianto, N., \& Haryoko, U. B. (2020). Progam Pendampingan Dan Penyelenggaraan Pendidikan Anak Pada Usia Dini Terhadap Prestasi Belajar Dilingkungan Rt 020 Rw 009. Kel Giri Peni. Kec Wates. Yogyakarta. Jurnal Lokabmas Kreatif, 1(1), 71-75.

[15] Pasaribu, V. L. D., Jannah, M., Fazar, M., Putra, S. P., Monalisa, M., \& Sofa, M. (2021). MENINGKATKAN PRODUKTIVITAS USAHA DIMASA PANDEMI PADA IBU PKK RT 004/003 KELURAHAN SAWAH BARU CIPUTAT, TANGERANG SELATAN. Abdi Laksana: Jurnal Pengabdian Kepada Masyarakat, 2(2), 295-301.

[16] Pasaribu, V. L. D., Yuniati, H. L., Pranata, R., Sembayu, R., Purba, S. M., \& Nurbayani, T. T. A. (2021). MANAJEMEN KEUANGAN UNTUK MENGHADAPI DAN BERTAHAN DI ERA COVID 19. Jurnal Abdimas Tri Dharma Manajemen, 2(2), 12-18.

[17] Pasaribu, V. L. D., Dwiyatni, A., Sabina, C., Ridwan, M., Gunawan, D. D., \& Noviani, B. C. (2021). EVALUASI PENERAPAN 3M DIMASA PANDEMIC COVID 19. Jurnal Abdimas Tri Dharma Manajemen, 2(2), 54-60.
[18] Pasaribu, V. L. D., Syafei, A. N., Farhan, A., Aufaizah, A., Irani, C., \& Firtiayani, S. R. (2021). PENGARUH DISPLIN PROTOKOL KESEHATAN TERHADAP PENCEGAHAN PENULARAN VIRUS COVID19. Jurnal Abdimas Tri Dharma Manajemen, 2(2), 91-98.

[19] Priadi, A., Pasaribu, V. L. D., Virby, S., Sairin, S., \& Wardani, W. G. (2020). Penguatan Ekonomi Kreatif Berbasis Sumber Daya Desa Dikelurahan Rempoa. Abdi Laksana: Jurnal Pengabdian Kepada Masyarakat, 1(3), 356-35 